\title{
Pola Pertumbuhan dan Identifikasi Genetik Turbo setosus Gmelin, 1791 [Turbinidae, Gastropoda]
}

\author{
Dandi Saleky', Febriyani Eka Supriyatin², Muhammad Dailami²* \\ IJurusan Manajemen Sumberdaya Perairan, Universitas Musamus \\ Jl. Kamizaun Mopah Lama, Merauke, 99600, Indonesia \\ 2Program Studi Budidaya Perairan, Fakultas Perikanan dan Ilmu Kelautan, Universitas Brawijaya \\ JI. Veteran, Kota Malang, 65149, Indonesia \\ Email: muhdailami@ub.ac.id
}

\begin{abstract}
Growth Pattern and Genetic Identification of Turbo setosus Gmelin, 1791 [Turbinidae, Gastropod]

Morphological dan genetic identification is an essential part of biology and ecological study. Environmental degradation, physical and chemical facto in water, and utilization of gastropod by society will give impact in distribution pattern, population size, morphology and genetic characteristic of the snail. This research aims to analyze the growth pattern and molecular aspect of Turbo setosus. The variable that examined is total weight and length, and cytochrome oxidase subunit one gene sequence. The growth factor of $T$. setosus is negative allometric, which means weight growth is slower than the length growth. The total length of cytochrome oxidase subunit 1 of these samples were 650 base pairs. Based on the DNA barcoding analysis, the sequence is $96.92 \%$ identic with the sequence of $T$. setosus in GenBank. The phylogenetic tree was reconstructed with neighbour-joining methods and 1000 replication bootstrap, show the clade grouping based on the similarity and genetic distance of the species. The sequence data is vital for species identification fast and accurately.
\end{abstract}

Keywords : growth; negative allometric; DNA barcoding; phylogenetic; Turbo setosus

\begin{abstract}
Abstrak
Identifikasi morfologi dan genetik menjadi bagian penting dari setiap studi biologi maupun ekologi, degradasi lingkungan, faktor fisik-kimia lingkungan dan pemanfaatan gastropoda secara terus menerus akan mempengaruhi penyebaran, penurunan populasi, karakteristik morfologi dan juga karakter molekuler spesies. Penelitian ini bertujuan untuk menganalisis pola pertumbuhan dan karakter molekuler Turbo setosus. Variabel yang diukur adalah berat total dan panjang total serta identifikasi molekuler dengan menggunakan gen sitokrom oksidase I. Pola pertumbuhan T. setosus adalah allometrik negatif yang berarti pertambahan berat lebih lambat dari pertambahan panjang. Hasil identifikasi dengan DNA barcoding diperoleh spesies T. setosus dengan panjang sekuen DNA 650 bp. Rekonstruksi filogenetik dengan metode Neighbor-Joining boostrap 1000x memperlihatkan pengelompokan sekuen berdasarkan kimiripan dan jarak genetik antar spesies. penting dalam identifikasi spesies secara cepat, tepat dan akurat.
\end{abstract}

Kata kunci : pertumbuhan; allometrik negatif; DNA barcoding; filogenetik; Turbo setosus

\section{PENDAHULUAN}

Gastopoda dan bivalvia banyak dimanfaatkan sebagai sumber bahan makanan dan protein bagi masyarakat
(Saleky et al., 2016; Soeharmoko, 2010). Degradasi lingkungan, faktor fisika-kimia perairan, lingkungan dan pemanfaatan gastropoda secara terus menerus akan mempengaruhi penyebaran, (Ramesh \& 
Ravichandran, 2008; Rumahlatu dan Leiwakabessy, 2017), ukuran populasi (Putra, Zainuri, \& Endrawati, 2014), karakteristik morfologi dan juga karakter molekuler spesies tersebut (Saleky et al., 2016). Keanekaragaman gastopoda yang tinggi menimbulkan kesulitan dalam identifikasi spesies (Layton, Martel, \& Hebert, 2014).

Identifikasi morfologi dan genetik menjadi bagian penting dari setiap studi biologi maupun ekologi, sehingga perlu dilakukan identifikasi spesies secara cepat, tepat dan akurat (Galan, Mendez, \& Cruz, 2018; Layton et al., 2014). Salah satu kunci identifikasi gastropoda secara morfologi adalah bagian cangkangnya (Galan et al., 2018). Selain itu, cangkang ini juga berperan penting sebagai perlindungan tubuhnya yang lunak dan juga perlindungan diri dari pemangsa (Sälgeback, 2006).

Penggunaan karakter morfologi dalam mengidentifikasi spesies gastropoda sering kali terjadi kesalahan akibat adanya kemiripan morfologi maupun warna (Rao et al., 2018). Selain itu, adanya struktur tambahan pada cangkang dan mereduksinya beberapa karakter cangkang (Karyanto \& Indrowati, 2004) juga berkontribusi dalam kesalahan identifikasi secara morfologi. Penggunaan DNA barcoding sebagai alat dalam mengidentifikasi spesies sangat penting ketika identifikasi dengan morfologi menemui kendala (Naseem \& Tahir, 2018). DNA barcoding telah banyak digunakan untuk melengkapi pendekatan morfologis dalam identifikasi spesies dan dalam merekonstruksi filogenetik (Hebert, Ratnasingham, \& de Waard, 2003a; 2003b). Kompleksitas lingkungan mempengaruhi struktur genetik baik keragaman dan juga jarak genetik dari gastropoda (Arnaud et al., 1999). DNA barcoding sebelumnya telah dilakukan pada kelompok gastropoda Turbinidae seperti Turbo sparverius, Turbo bruneus, Lunella sp. serta digunakan dalam menguji bahan makanan, mengidentifikasi parasit serta memantau perdagangan ilegal suatu spesies (Tahir \& Akhtar, 2016).

Kepala Burung Papua kaya akan sumberdaya alam yang memiliki berbagai jenis gastropoda, salah satunya yaitu bia mata bulan (Turbo sp.) (Saleky et al., 2016). Penelitian ini dilakukan untuk menginventarisir Turbo sp. di daerah Kepala Burung Papua (Headbird Seascape Papua). Data yang dihasilkan dapat menunjang kegiatan pengelolaan dan konservasi sumberdaya khususnya dalam menghadapi masalah masalah lingkungan seperti fragmentasi habitat dan tekanan antropogenik (Layton et al., 2014).

\section{MATERI DAN METODE}

Sampel diambil di perairan Pulau Mansinam Kabupaten Manokwari Papua Barat (Gambar 1). Sampel dikoleksi pada malam hari saat terjadinya surut air laut dengan cara koleksi bebas. Jumlah sampel yang diambil adalah 123 individu.

Identifikasi morfologi dilakukan dengan menggunakan buku identifikasi gastropoda Indonesian Shells I (Dharma, 1988) dan Recent \& Fossil Indonesian Shell (Dharma, 2005). Pengukuran morfometrik dilakukan dengan mengukur panjang cangkang dan berat total dengan menggunakan jangka sorong dan timbangan digital, dilanjutkan dengan pengambilan sampel jaringan (tissue) untuk analisis DNA. Sampel jaringan disimpan dan diawetkan menggunakan etanol $96 \%$ sampai digunakan.

\section{Analisis molekuler}

Genom DNA diambil dari bagian kaki perut $T$. setosus. Proses Isolasi DNA dilakukan dengan menggunakan DNA extraction kit (Qiagen kit, USA) dengan prosdeur standar dari produsen. Perbanyakan $\mathrm{COI}$ menggunakan Teknik polymerase chain reaction (PCR) dengan primer forward LCO1490 (5'-ggtcaacaaatcataaagatattgg3') dan primer reverse HCO2198 (5'taaacttcagg gtgaccaaaaaatca-3') (Folmer et al, 1994). Reaksi PCR dilakukan dalam total volume $25 \mu \mathrm{l}$ dengan jumlah template DNA 1 - $4 \mu \mathrm{l}$. Profil suhu dalam proses PCR yaitu denaturasi $94{ }^{\circ} \mathrm{C}$, annealing $50^{\circ} \mathrm{C}$, dan extension $72^{\circ} \mathrm{C}$. Produk PCR dielektroforesis untuk dengan menggunakan gel agarosa $1 \%$, buffer TBE dengan tegangan 100-volt selama 30 menit. Pewarnaan DNA dilakukan 


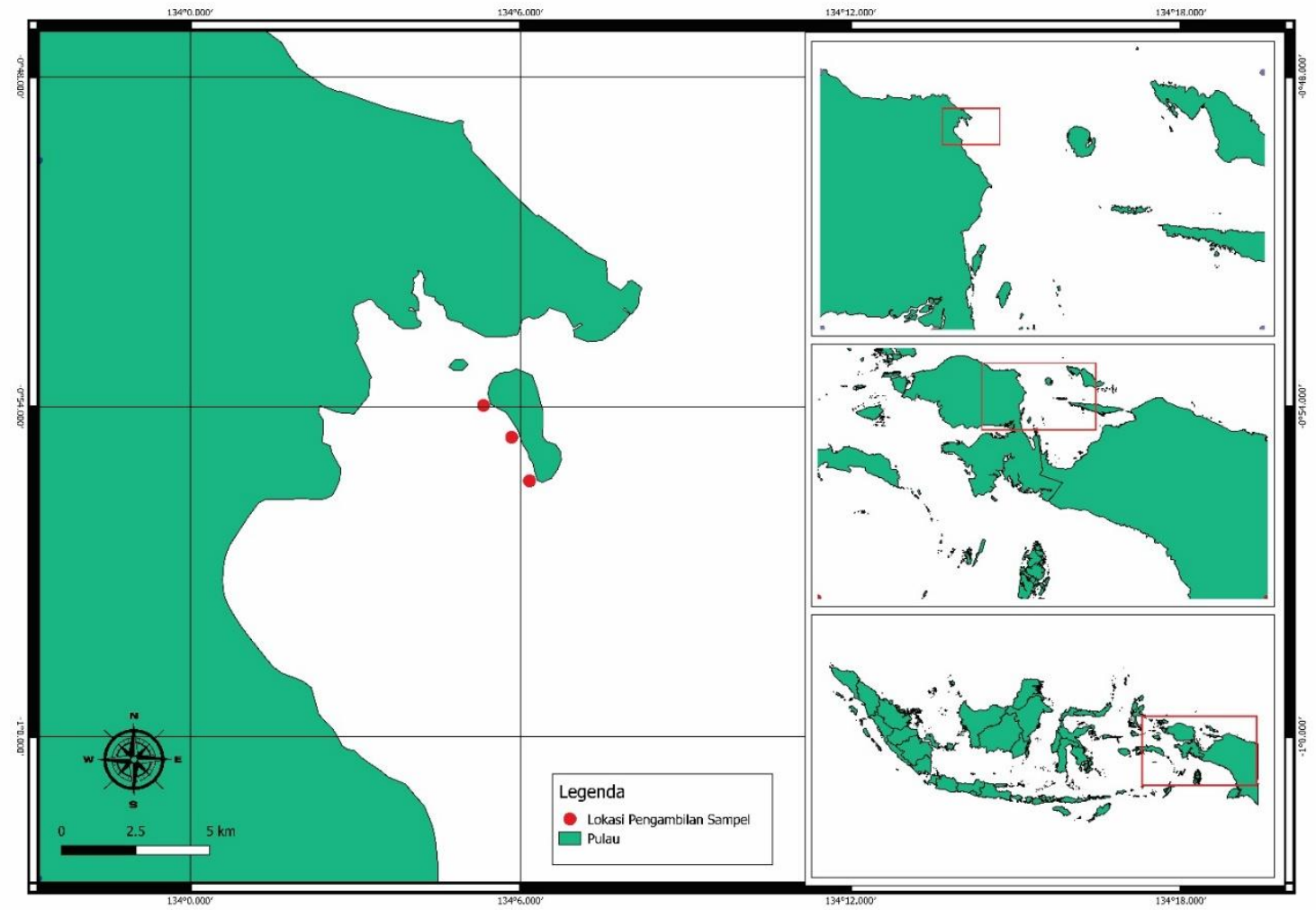

Gambar 1. Lokasi penelitian Morfogenetik Turbo setosus

dengan menggunakan Etidium Bromida dan divisualisasi menggunakan UV transluminator. Sekuensing dilakukan dengan mengirim produk PCR ke lembaga $1^{\text {st }}$ Base Malaysia.

\section{Analisis Data}

Panjang dan berat total adalah variabel terukur dalam penelitian ini. Analisis panjang-berat menggunakan uji regresi linear dengan menggunakan software Microsoft Excel 2010 dengan rumus: $W=a L^{b}$ yang mana $W$ adalah berat tubuh (gram), L adalah panjang tubuh $(\mathrm{mm})$ sedangkan nilai a dan b adalah konstanta.

Data sekuen DNA dari dua rah yaitu forward dan reverse, disesuaikan dengan elektroferogram yang dihasilkan. Penjajaran (alignment) menghasilkan satu sekuens dengan urutan yang sama dan disimpan dalam format fasta. Sekuens dari semua sampel disejajarkan (alignment) dengan metode ClustalW (1.6) (Kumar, Stecher, \& Tamura, 2016) dalam program MEGA (Moleculer Evolutionary Genetic Analysis) 6
(Tamura et al., 2013). Data sekuen DNA dibandingkan dengan data GenBank (National Center for Biotechnology Information (NCBI) dengan aplikasi BLAST (basic local alignment search tools) (Morgulis et al., 2008) untuk menentukan spesies berdasarkan data pembanding yang tersedia di GenBank. Analisis DNA juga dilanjukan dengan menghitung jarak genetik antar spesies dan juga analisis pohon filogenetik Turbo sp. menggunakan metode Neighbor-Joining (NJ) (Saitou \& Nei, 1987) dengan model Kimura 2-parameter, nilai bootstrap 1000x (Efron, Halloran, \& Holmes, 1996).

\section{HASIL DAN PEMBAHASAN}

Jumlah sampel gastropoda yang diambil dari Pulau Mansinam Kabupaten Manokwari Papua Barat sebanyak 123 individu. Hasil identifikasi morfologi menunjukkan bahwa sampel tersebut adalah dari spesies Turbo setosus. Sampel ini memiliki operculum yang berwarna putih dengan corak hijau gelap. Cangkang bagian 
dalamnya berwarna putih dan cangkang luar berwarna hijau kehitaman. Pada bagian luar cangkang terdapat lurik yang cembung sehingga mebuat cangkangnya seakan bergelombang kecil. Adapun foto morfologi dari sampel yang dianalisis yaitu disajikan pada Gambar 2.

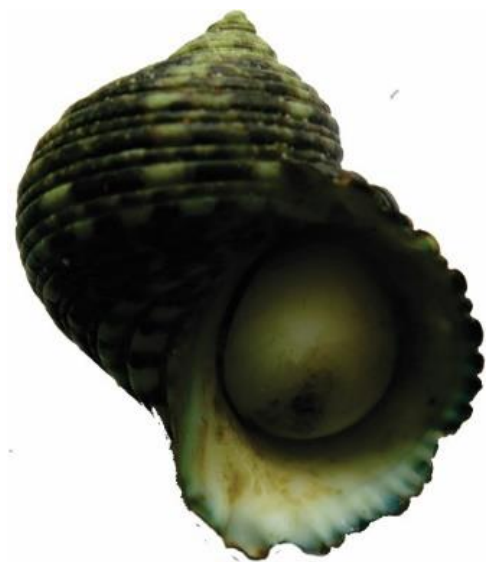

Gambar 2. Bentuk Morfologi Turbo setosus

Turbo setosus merupakan gastropoda laut yang termasuk dalam famili Turbinidae yang dimanfaatkan oleh masyarakat pesisir sebagai sumber makanan yang mengandung berbagai protein dan mineral (Lestari, Azrianingsih, \& Hendrian, 2018). Spesies ini, secara ekologi menjadi bagian yang tidak terpisahkan dari rantai makanan yang ada di perairan (Srimariana, 2015). T. setosus kebanyakan hidup pada daerah intertidal berbatu (Baharuddin, Basir, \& Zainuddin, 2019; Saleky et al., 2019).

\section{Hubungan Panjang Berat dan Pola Pertumbuhan}

Hasil pengukuran Panjang dan berat dari sampel $T$. Setosus, diperoleh nilai panjang total berkisar 32.27 - $60.02 \mathrm{~mm}$ dan berat total berkisar 10.9 - 67.29 gr. Hewan ini dapat mencapai ukuran $6-7 \mathrm{~cm}$ dan berada di perairan yang tenang (Dharma, 2005) dan dapat ditemukan pada daerah intertidal berbatu di pesisir utara. Spesies $T$. setosus sering ditemukan hidup bersama dengan spesies lain seperti T. sparverius dan T. bruneus (Saleky et al., 2019, 2016).

Hasil perhitungan panjang berat $T$. setosus diperoleh persaman $\mathrm{W}=0.00057 \mathrm{~L}^{2.841}$ dengan nilai $R^{2}=0.953$, dimana $W$ adalah berat (gram) dan L adalah Panjang (cm). Hubungan panjang dan berat total $T$. setosus yang diperoleh menunjukkan hubungan linier dengan persamaan garis $Y=0.4898 x+30.229$ dengan nilai koefisien korelasi $r=0.976$ dan nilai $R^{2}=0.953$ (Gambar 3). Berdasarkan nilai $R^{2}$ yang diperoleh menunjukkan bahwa kontribusi panjang cangkang terhadap berat adalah $0.953 \%$. Hubungan ini juga menunjukkan ukuran panjang cangkang dapat diduga dari ukuran bobot tubuh.

Pola pertumbuhan $T$. setosus dapat dilihat dari nilai $b$ pada hasil regresi linear yaitu sebesar $2.841462 \quad(<3)$ yang menunjukkan nilai yang lebih rendah dari 3 . Hasil tersebut mengindikasikan bahwa pola

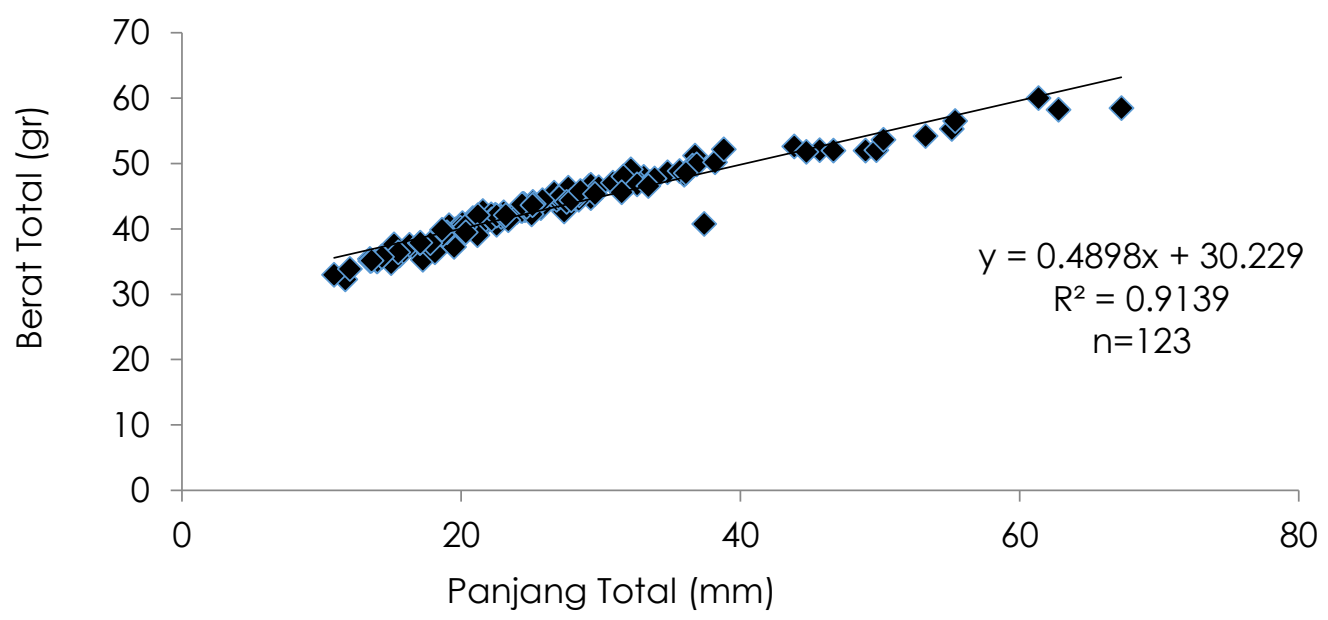

Gambar 3. Regresi linear hubungan panjang-berat $T$. setosus 
pertumbuhan relatif $T$. setosus yang dikoleksi dari Pulau Mansinam Manokwari adalah allometrik negatif yang dapat diartikan bahwa penambahan berat lebih lambat dari pada panjang. Pola pertumbuhan allometrik negatif juga ditemukan pada jenis $T$. bruneus, T. sparverius (Saleky et al., 2016), Modiolus modulaides (Zabarun, 2016) dan Strombus Iuhuanus (Jala, Haumahu, \& Uneputty, 2014). Pertumbuhan gastropoda dicirikan dengan bertambahnya ukuran dan bobot yang dipengaruhi oleh berbagai faktor seperti makanan, jenis kelamin, faktor fisik-kimia perairan (Jala et al., 2014).

\section{Karakter Molekuler}

DNA sekuens yang dihasilkan dari hasil amplifikasi dan sekuensing gen sitokrom oksidase I (COI) gastropoda yang dikoleksi di Pulau Mansinam Manokwari, Papua barat memiliki panjang sekuen DNA 650 pasang basa (pb). Hasil identifikasi dengan teknik DNA barcoding menunjukkan bahwa sampel dalam penelitian ini adalah spesies $T$. setosus dengan tingkat similaritas $95.85-96.92 \%$ dan query coverage sebesar $100 \%$ (Tabel 1).

Semua sekuens gen COI dari sampel T. setosus tidak semuanya memiliki urutan basa nukleotida yang identik. Terdapat 10 titik perbedaan nukleotida yang ditemukan dalam sekuens tersebut (Tabel 3). Terdapat 8 titik perbedaan yang terjadi akibat adanya mutasi dari basa A menjadi $G$ atau sebaliknya, dan juga ditemukan 2 perbedaan nukleotida yang diakibatkan oleh mutasi dari basa $C$ menjadi T. Mutasi antara basa $G$ dan A lebih banyak ditemukan pada sampel ini dari pada mutase antara A dan T.

DNA barcoding menjadi teknik identifikasi spesies dan membantu mempercepat penemuan spesies baru (Tahir et al., 2016). Keragaman DNA mitokondria terutama disebabkan oleh tingkat mutasi yang tinggi dan memiliki implikasi potensial untuk morfologi dan evolusi (Fourdrilis, Martins, \& Backeljau, 2018). Gen COI dapat digunakan sebagai marka gen dalam identifikasi dan taksonomi baik pada tingkatan populasi maupun spesies (Nuryanto \& Solihin, 2006), dalam kegiatan pengelolaan dan juga konservasi spesies penting dari kepunahan (Ghosh et al., 2019).

Kandungan nukleotida $\mathrm{G}+\mathrm{C}$ dari seluruh sampel T. Setosus rata rata sebesar $36.95 \%$ sedangkan kandungan A+T sebesar $63.05 \%$ (Tabel 2). Kandungan A+T sampel ini lebih rendah dari pada kandungan $\mathrm{G}+\mathrm{C}$ yang menjadikan sekuens ini mudah didenaturasi pada saat proses amplifikasi dengan menggunakan polymerase chain reaction. Suhu denaturasi yang digunakan dalam proses PCR sampel ini yaitu $94^{\circ} \mathrm{C}$, yang termasuk dalam kategori relative rendah.

Tabel 1. Hasil identifikasi dengan menggunakan BLAST (Basic Local Alignment Search Tool)

\begin{tabular}{cllcc}
\hline No & Identifikasi spesies & Lokasi & Query Coverage (\%) & Hasil BLAST (\%) \\
\hline 1 & Turbo setosus & Pulau Mansinam, Manokwari & 100 & 96.92 \\
2 & Turbo setosus & Pulau Mansinam, Manokwari & 100 & 95.85 \\
3 & Turbo setosus & Pulau Mansinam, Manokwari & 100 & 96.92 \\
4 & Turbo setosus & Pulau Mansinam, Manokwari & 100 & 96.77 \\
\hline
\end{tabular}

Tabel 2. Komposisi nukleotida T. setosus asal Pulau Mansinam

\begin{tabular}{lcccccc}
\hline Spesies & $\mathrm{T}(\%)$ & $\mathrm{C}(\%)$ & $\mathrm{A}(\%)$ & $\mathrm{G}(\%)$ & $\mathrm{C}+\mathrm{G}(\%)$ & $\mathrm{A}+\mathrm{T}(\%)$ \\
\hline Turbo setosus-1 & 39.4 & 16.1 & 23.4 & 21.1 & 37.2 & 62.8 \\
Turbo setosus-2 & 39.7 & 15.8 & 23.9 & 20.6 & 36.4 & 63.6 \\
Turbo setosus-3 & 39.4 & 16.1 & 23.4 & 21.1 & 37.2 & 62.8 \\
Turbo setosus-4 & 39.4 & 16.1 & 23.6 & 20.9 & 37 & 63 \\
\hline Rata - rata & 39.5 & 16.0 & 23.6 & 20.9 & 36.95 & 63.05 \\
\hline
\end{tabular}


Tabel 3. Tabel mutasi gen COI yang menyebabkan polimorfisme dari 4 sampel T. setosus

\begin{tabular}{lllllllllll}
\hline & 68 & 146 & 197 & 254 & 370 & 476 & 500 & 503 & 554 & 629 \\
\hline Turbo setosus (1) & A & G & G & G & C & A & G & G & C & G \\
Turbo setosus (2) & G & A & A & A & T & G &. & A & T & A \\
Turbo setosus (3) &. &. &. &. &. &. &. &. &. &. \\
Turbo setosus (4) & . &. &. &. &. &. & A &. &. &. \\
\hline
\end{tabular}

Sekuen DNA T. setosus dapat mengalami perubahan yang disebut mutasi. DNA mitokondrai dan DNA inti memiliki laju mutasi yang berbeda yang dapat menggambarkan perbedaan aspek sejarah dan biologi populasi (Sunnucks, 2000). Mutasi gen dapat terjadi secara spontaneous mutation dan induced mutation yang dapat berdampak baik ataupun negatif yang dapat berupa transition ataupun mutasi transvertion (Sobrizal, 2017). Mutasi antara basa $G$ dan $A$, basa $C$ dan T disebut sebagai mutase transisi karena terjadi antar basa purin dengan purin atau pirimidin dengan pirimidin. Mutasi transisi merupakan mutase yang sering terjadi dibandingkan dengan mutasi transversi, karena mutasi ini umumnya bersifat nonsynonymous. Perubahan nukleotida dapat terjadi akibat dari pola adaptasi organisme terhadap perubahan lingkungan (Prehadi et al., 2015). Terdapat beberapa jenis mutasi lain yang biasa terjadi pada makhluk hidup yaitu delesi, inversi, translokasi dan transposisi (Nuryanto \& Solihin, 2006).

Analisis haplotype dari ke 4 sekuen DNA T. setosus diperoleh 3 haplotipe yang berbeda dengan keanekaragaman haplotype sebesar 0.83 (Tabel 4). Pengelompokan haplotype tersebut didasarkan pada adanya perbedaan urutan sekuens gen COI dari sampel yang dianalisis. Sampel satu dan tiga memiliki urutan sekuens yang $100 \%$ identik sehingga dapat dikelompokkan menjadi satu haplotype. Berbeda halnya dengan sampel 2 dan 4 yang memiliki perbedaan nukleotida dari sampel 1 dan 3 , sehingga dipisahkan menjadi haplotype tersendiri.

Haplotype adalah sekelompok alel dalam suatu organisme yang diwarisi dari induk kepada keturunannya (Bergstrom, 2001). Keragaman haplotype sangat penting bagi kehidupan kelompok organisme, karena memungkinkan suatu spesies dapat bertahan terhadap perubahan lingkungan. Keragaman genetik yang rendah meningkatkan risiko kepunahan karena mengurangi potensi spesies untuk beradaptasi dengan perubahan lingkungan (Hobbs, Herwerden, Jerry, Jones, \& Munday, 2013).

Tabel 4. Daftar haplotipe gen $\mathrm{CO}$ dari 4 sampel T. setosus

\begin{tabular}{cc}
\hline Haplotipe & Sekuen DNA \\
\hline 1 & 1,3 \\
2 & 2 \\
3 & 4 \\
\hline
\end{tabular}

Jumlah haplotype sangat dipengaruhi oleh jumlah sampel yang dianalisis, kemungkinan jumlah haplotype akan bertambah dengan bertambahnya jumlah sampel yang dianalisis. Hasil analisis juga memperlihatkan haplotype $T$. setosus asal Pulau Mansinam berbeda dengan haplotype $T$. setosus yang dikoleksi dari Taiwan (Williams, 2007). Kondisi tersebut dapat terjadi akibat tidak terjadinya aliran karakter genetik antar populasi $T$. setosus. Organisme laut seperti gastropoda cenderung menetap dan mengalami fase larva planktonik. Hal ini yang menyebabkan gastropoda cendrung memiliki struktur genetik yang lebih rendah dibandingkan dengan organisme yang aktif berpindah (Kyle \& Boulding, 2000).

Rekonstruksi pohon filogenetik T. setosus (Gambar 4) dibentuk dari 4 sekuen DNA T. setosus asal Pulau Mansinam dengan beberapa sekuen DNA dari GenBank dan Trochus niloticus (Geiger \& Thacker, 2005) dan Trochus_maculatus (Kano, 2007) sebagai out grup. Informasi mengenai asal lokasi, nomor akses sekuens Genbank dan referensinya disajikan dalam Tabel 5. Pohon filogenetik membentuk 2 clade yaitu clade 1 terdiri atas 
spesies $T$. setosus, $T$. sparverius dan $T$. bruneus dan clade 2 terdiri atas spesies T. marmoratus, $T$. revii, $T$. jourdani dan $T$. petholatus. $T$. setosus asal Mansinam juga membentuk clade yang sama dengan T. setosus asal Taiwan dengan nilai boostrap 100.

Sejarah populasi dan spesies dari berbagai tingkat kehidupan dapat dipelajari dari pohon filogenetik berdasarkan data molekuler (Grande et al., 2004). Filogenetik merupakan klasifikasi secara taksonomi spesies berdasarkan sejarah evolusi, analisis yang dilakukan berdasarkan analisis sekuen DNA spesies. Model matematika digunakan dalam menyimpulkan sejarah evolusi spesies melalui data molekuler (Yuan, Zhu, \& Liu, 2014). Tingginya nilai boostrap mempengaruhi rekonstruksi filogenetik yang terbentuk, semakin tinggi nilai boostrap maka semakin baik pohon yang terbentuk (Horiike et al., 2009).

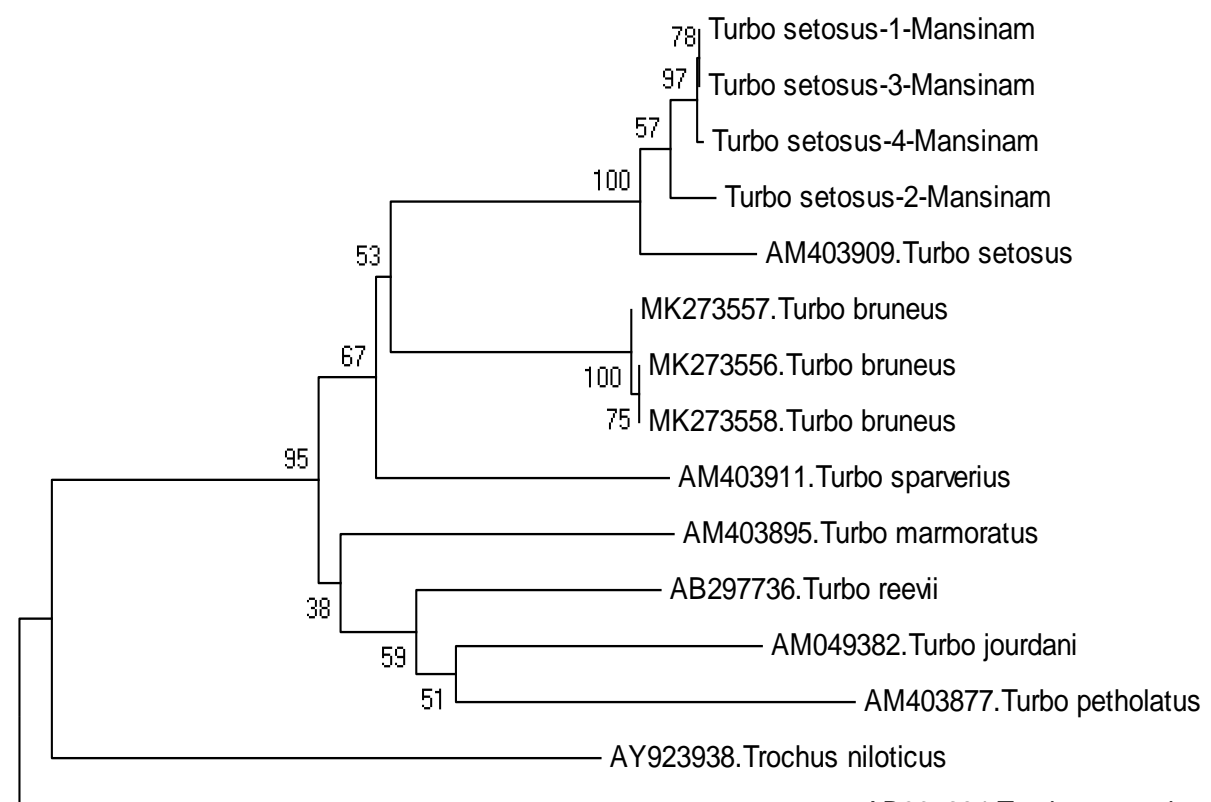

AB365224. Trochus maculatus

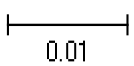

Gambar 4. Rekonstruksi pohon filogenetik dengan metode Neighbor-Joining menggunakan 11 sekuen DNA dari GenBank dengan Trochus niloticus dan Trochus maculatus sebagai out grup.

Tabel 5. Sekuens gen COI dari GenBank NCBI yang digunakan dalam pembuatan pohon filogenetik

\begin{tabular}{|c|c|c|c|c|}
\hline No & Species & Lokasi & Acc. GenBank & Referensi \\
\hline 1 & T. bruneus & Manokwari, Papua barat & MK273558 & (Saleky et al., 2016) \\
\hline 2 & T. bruneus & Manokwari, Papua barat & MK273557 & (Saleky et al., 2016) \\
\hline 3 & T. bruneus & Manokwari, Papua barat & MK273556 & (Saleky et al., 2016) \\
\hline 4 & T. setosus & Taiwan & AM403909 & (Williams, 2007) \\
\hline 5 & T. sparveius & Taiwan & AM403911 & (Williams, 2007) \\
\hline 6 & T. reevii & Ogasawara Islands, Japan & AB297736 & $\begin{array}{c}\text { (Nakano, Takahashi, \& } \\
\text { Ozawa, 2007) }\end{array}$ \\
\hline 7 & T. petholatus & Japan & AM403877 & (Williams, 2007) \\
\hline 8 & T. jourdani & Japan & AM049382 & (Williams \& Ozawa, 2006) \\
\hline 9 & T. mamoratus & Japan & AM403895 & (Williams, 2007) \\
\hline 10 & Trochus niloticus & Moorea, French Polynesia & AY923938 & (Geiger \& Thacker, 2005) \\
\hline 11 & T. maculatus & Japan & AB365224 & (Kano, 2007) \\
\hline
\end{tabular}


Tabel 6. Jarak genetik sekuens gen $\mathrm{COI}$ dari T. setosus

\begin{tabular}{|c|c|c|c|c|c|c|c|c|c|c|c|c|c|c|}
\hline Spesies & 1 & 2 & 3 & 4 & 5 & 6 & 7 & 8 & 9 & 10 & 11 & 12 & 13 & 14 \\
\hline Turbo setosus-1- & & $*$ & * & * & * & * & * & * & * & * & * & * & * & * \\
\hline Turbo setosus-2- & & & * & * & * & * & * & * & * & * & * & * & * & * \\
\hline Mansinam & 0.006 & & & & & & & & & & & & & \\
\hline Turbo setosus-3- & & & & & * & * & * & * & * & * & * & * & * & * \\
\hline Mansinam & 0.000 & 0.006 & & * & & & & & & & & & & \\
\hline Turbo setosus-4- & & & & & $*$ & $*$ & $*$ & $*$ & $*$ & $*$ & $*$ & * & * & * \\
\hline $\begin{array}{l}\text { Mansinam } \\
\text { AM403911.Turbo }\end{array}$ & 0.001 & 0.007 & 0.001 & & & & * & * & * & * & * & * & * & * \\
\hline sparverius & 0.053 & 0.049 & 0.053 & 0.052 & & * & & & & & & & & \\
\hline MK273557.Turbo & & & & & & & * & * & * & * & * & * & * & * \\
\hline $\begin{array}{l}\text { bruneus } \\
\text { MK273556.Turbo }\end{array}$ & 0.047 & 0.045 & 0.047 & 0.047 & 0.045 & & & & * & * & * & * & * & * \\
\hline $\begin{array}{l}\text { bruneus } \\
\text { MK273558.Turbo }\end{array}$ & 0.048 & 0.046 & 0.048 & 0.047 & 0.046 & 0.001 & & $*$ & * & * & * & * & * & * \\
\hline $\begin{array}{l}\text { bruneus } \\
\text { AM403909 Turbo }\end{array}$ & 0.048 & 0.046 & 0.048 & 0.047 & 0.046 & 0.001 & 0.000 & & & & * & * & * & * \\
\hline $\begin{array}{l}\text { setosus } \\
\text { AM049382.Turbo }\end{array}$ & 0.014 & 0.019 & 0.014 & 0.014 & 0.059 & 0.050 & 0.051 & 0.051 & & * & * & * & * & * \\
\hline $\begin{array}{l}\text { jourdani } \\
\text { AM403877.Turbo }\end{array}$ & 0.072 & 0.070 & 0.072 & 0.071 & 0.064 & 0.058 & 0.059 & 0.059 & 0.076 & & & & * & * \\
\hline $\begin{array}{l}\text { petholatus } \\
\text { AB297736.Turbo }\end{array}$ & 0.081 & 0.077 & 0.081 & 0.081 & 0.077 & 0.072 & 0.073 & 0.073 & 0.083 & 0.059 & & * & * & * \\
\hline $\begin{array}{l}\text { reevii } \\
\text { AM403895.Turbo }\end{array}$ & 0.059 & 0.058 & 0.059 & 0.058 & 0.061 & 0.056 & 0.057 & 0.057 & 0.067 & 0.048 & 0.059 & & & \\
\hline $\begin{array}{l}\text { marmoratus } \\
\text { AY923938.Trochu }\end{array}$ & 0.065 & 0.061 & 0.065 & 0.065 & 0.054 & 0.054 & 0.055 & 0.055 & 0.063 & 0.060 & 0.067 & 0.059 & & $*$ \\
\hline $\begin{array}{l}\text { s niloticus } \\
\text { AB365224.Trochu }\end{array}$ & 0.100 & 0.099 & 0.100 & 0.100 & 0.104 & 0.096 & 0.095 & 0.095 & 0.105 & 0.108 & 0.107 & 0.099 & 0.091 & \\
\hline s_maculatus & 0.126 & 0.129 & 0.126 & 0.125 & 0.122 & 0.127 & 0.126 & 0.126 & 0.128 & 0.136 & 0.119 & 0.123 & 0.136 & 0.119 \\
\hline
\end{tabular}

Jarak genetik antar individu T. setosus asal Pulau Mansinam sebesar $0-0.7 \%$, sedangkan jarak genetik $T$. setosus asal Pulau Mansinam dengan $T$. setosus asal Taiwan berkisar 1.4 - $1.9 \%$. Jarak genetik rata-rata semua sampel sebesar $6.7 \%$. Jarak genetik dalam spesies yang sama adalah kurang dari $4 \%$ sedangkan antar spesies lebih dari $4 \%$.

\section{KESIMPULAN}

Pertumbuhan dari T. setosus yang diambil dari daerah adalah alometrik negatif, artinya pertumbuhan Panjang tubuhnya lebih cepat dari pada berat tubuhnya. Data sekuens gen $\mathrm{COI}$ yang diperoleh memiliki Panjang 650 pasang basa dan memiliki kemiripan antara 95.85 - $96.92 \%$ dengan sekuens T. setosus dari GenBank. Pohon filogenetik menunjukkan bahwa sekuens $T$. setosus asal pulau Mansinam berada dalam satu kelompok dengan T. setosus dari Genbank dengan dukungan nilai bootstrap $100 \%$.

\section{DAFTAR PUSTAKA}

Arnaud, J., Madec, L., Bellido, A., \& Guiller, A.,1999. Microspatial genetic structure in the land snail Helix aspersa (Gastropoda: Helicidae). Heredity, 83:110-119. doi: 10.1046/j.1365-2540.1999.00565.x

Baharuddin, N., Basir, N. H. M., \& Zainuddin, S. N. H., 2019. Tropical intertidal gastropods: Insights on diversity, abundance, distribution and shell morphometrics of Pulau Bidong, Malaysia. AACL Bioflux, 12(4): 1375-1387.

Bergstrom, D. E., 2001. Haplotype. In S. Brenner \& J. H. Miller (Eds.), Encyclopedia of Genetics (pp. 911-912). doi: 10.1006/rwgn.2001.0584

Coenye, T., \& Vandamme, P., 2003. Extracting phylogenetic information from wholegenome sequencing projects: The lactic acid bacteria as a test case. Microbiology, 149(12): 3507-3517. doi: 10.1099/mic.0.26515-0

Dharma, B., 1988. Indonesian shells I. California: Hemmen. 135 p. 
Dharma, B., 2005. Recent and Fossil Indonesian Shells. California: Hemmen. $424 \mathrm{p}$.

Efron, B., Halloran, E., \& Holmes, S.,1996. Bootstrap confidence levels for phylogenetic trees. Proc. Natl. Acad. Sci. U.S.A, 93(23):13429-13434. doi: 10.1073/pnas.93.14.7085

Folmer, O., Black, M., Hoeh, W., Lutz, R., \& Vrijenhoek, R., 1994. DNA primers for amplification of mitochondrial cytochrome c oxidase subunit I from diverse metazoan invertebrates. Mol. Mar. Biol. Biotechnol., 3(5): 294-299.

Fourdrilis, S., Martins, A.M. de F., \& Backeljau, T., 2018. Relation between mitochondrial DNA hyperdiversity, mutation rate and mitochondrial genome evolution in Melarhaphe neritoides (Gastropoda: Littorinidae) and other Caenogastropoda. Sci. Rep., 8(17964): 112. doi: $10.1038 / s 41598-018-36428-7$

Galan, G. L., Mendez, N. P., \& Cruz, R. Y. Dela., 2018. DNA bacoding of three selected gastropod species using cytochrome oxidase (COI) gene. An. West University Timisoara, Ser. Biolog., 21 (1): 93-102.

Geiger, D.L., \& Thacker, C.E., 2005. Molecular phylogeny of Vetigastropoda reveals non-monophyletic Scissurellidae, Trochoidea, and Fissurelloidea. Mollusc. Res., 25(1):47-55. doi: 10.1.1.435.4190

Ghosh, A., Basu, S., Khatri, H., Chandra, K., \& Thakur, M., 2019. Ascertaining species of origin from confiscated meat using DNA forensics. Mitochon. DNA Part B: Res., 4(1):329-331.

doi: $10.1080 / 23802359.2018 .1544041$

Grande, C., Templado, J., Cervera, J.L., \& Zardoya, R., 2004. Phylogenetic relationships among Opisthobranchia (Mollusca: Gastropoda) based on mitochondrial cox 1, trnV, and $\mathrm{rrnL}$ genes. Mol. Phylogenet. Evol., 33(2): 378-388. doi: 10.1016/j.ympev.2004.06.008

Hebert, P.D.N., Cywinska, A., Ball, S.L., \& de Waard, J.R., 2003a. Biological identifications through DNA barcodes. Proc. Royal Soc. B, 270(1512): 313-321. doi: $10.1098 / \mathrm{rspb} .2002 .2218$

Hebert, P.D.N., Ratnasingham, S., \& de Waard, J.R., 2003b. Barcoding animal life: cytochrome C oxidase subunit 1 divergences among closely related species. Proc. Royal Soc. B., 270:96-99. doi: 10.1098/rsbl.2003.0025

Hobbs, J.P., Herwerden, L. van, Jerry, D., Jones, G., \& Munday, P., 2013. High Genetic Diversity in Geographically Remote Populations of Endemic and Widespread Coral Reef Angelfishes (genus: Centropyge). Diversity, 5(1):3950. doi: 10.3390/d5010039

Horiike, T., Miyata, D., Hamada, K., Saruhashi, S., Shinozawa, T., Kumar, S., Tateno, Y., 2009. Phylogenetic construction of 17 bacterial phyla by new method and carefully selected orthologs. Gene, 429: 59-64. doi: 10.1016/j.gene.2008.10.006

Jala, S., Haumahu, S., \& Uneputty, P., 2014. Variasi Morfometrik dan Hubungan Panjang Berat. J. Triton, 10(2): 122-130.

Kano, Y., 2007. Vetigastropod phylogeny and a new concept of Seguenzioidea: independent evolution of copulatory organs in the deep-sea habitats. Zool. Scr., 37(1):1-21. doi: 10.1111/j.1463-6409. 2007.00316.x

Karyanto, P., \& Indrowati, M., 2004. Cangkang Gastropoda Ekosistem Mangrove Ekosistem Mangrove Cilacap Sebagai Alternatifsumber Pembelajaran Moluska; Gastropoda. Bioedukasi, 1(1):1-6. doi: 10.20961/bioedukasi-uns.v1i1.3984

Kumar, S., Stecher, G., \& Tamura, K., 2016. MEGA7: Molecular Evolutionary Genetics Analysis Version 7.0 for Bigger Datasets. Mol. Biol. Evol., 33(7):1870-1874. doi: 10.1093/molbev/msw054

Kyle, C.J., \& Boulding, E.G., 2000. Comparative population genetic structure of marine gastropods ( Littorina spp.) with and without pelagic larval dispersal. Mar. Biol., 137:835-845. doi: 10.1007/s002270000412

Layton, K.K.S., Martel, A.L., \& Hebert, P.D., 2014. Patterns of DNA Barcode Variation in Canadian Marine Molluscs. PLOS ONE, 9(4):1-9.

doi: 10.1371/journal.pone.0095003

Lestari, D.A., Azrianingsih, R., \& Hendrian, H., 2018. Filogenetik Jenis-jenis Annonaceae dari Jawa Timur Koleksi Kebun Raya Purwodadi Berdasarkan Coding dan Non-coding sekuen DNA. J. Trop. Biodiv. Biotechnol., 3:1-7. doi: 10.22146/jtbb.28 308 
Morgulis, A., Coulouris, G., Rayłselis, Y., Madden, T.L., Agarwala, R., \& Schäffer, A.A., 2008. Database indexing for production MegaBLAST searches. Bioinformatics, 24(16):1757-1764. doi: 10.1093/bioinformatics/btn322

Nakano, T., Takahashi, K., \& Ozawa, T., 2007. Description of an Endangered New Species of Lunella (Gastropoda:Turbinidae) from the Ogasawara Islands, Japan. J. Malacolog. Soc. Japan, 66(1): 1-10. doi: 10.18941/venus.66.1-2_1

Naseem, S., \& Tahir, H.M., 2018. Use of mitochondrial $\mathrm{COl}$ gene for the identification of family Salticidae and Lycosidae of spiders. Mitochondrial DNA Part A, 29(1): 96-101. doi: $10.1080 / 24701394.2016 .1248428$

Nuryanto, A., \& Solihin, D.D., 2006. Variasi Sekuens Gen Mitokondrial Sitokrom C Oksidase I dari Siput Lola (Trochus niloticus). Biosfera, 23(1): 31-37. doi: 10.20884/1.mib.2006.23.1.143

Prehadi, P., Sembiring, A., Kurniasih, E.M., Rahmad, R., Arafat, D., Subhan, B., \& Madduppa, H.H., 2015. DNA barcoding and phylogenetic reconstruction of shark species landed in Muncar fisheries landing site in comparison with Southern Java fishing port. Biodiversitas, J. Biolog. Div., 16(1):55-61. doi: 10.13057/biodiv/d160107

Putra, Y.A., Zainuri, M., \& Endrawati, H., 2014. Kajian Morfometri Gastropoda Di Perairan Pantai Desa Tapak Kecamatan Tugu Kota Semarang. J. Mar. Res., 3(4):566-577. doi: 10.14710/jmr.v3i4.11416

Ramesh, R., \& Ravichandran, S., 2008. Seasonal Variation on the Proximate Composition of Turbo brunneus. International Journal of Zoological Research, 4(1): 28-34. Doi: 10.3923/ijzr.2008.28.34

Rumahlatu, D., \& Leiwakabessy, F., 2017. Biodiversity of gastropoda in the coastal waters of ambon island, Indonesia. AACL Bioflux, 10(2):285-296.

Saitou, N., \& Nei, M.,1987. The neighborjoining method: a new method for reconstructing phylogenetic trees. Mol. Biol. Evol., 4(4):406-425. doi: 10.1093/oxfordjournals.molbev.a040454
Saleky, D., Leatemia, S. P., Yuanike, Y., Rumengan, I., \& Putra, I.N.G., 2019. Temporal Distribution of Gastropods In Rocky Intertidal Area In North Manokwari, West Papua. J. Sumberdaya Akuatik Indopasifik, 1-10. doi: 10.30862/jsai-fpikunipa.2019.vol.3.no.1.58

Saleky, D., Setyobudiandi, I., Toha, A.H.A., Takdir, M., \& Madduppa, H.H., 2016. Length-weight relationship and population genetic of two marine gastropods species (Turbinidae: Turbo sparverius and Turbo bruneus) in the Bird Seascape Papua, Indonesia. Biodiv. J.Biol. Div., 17(1): 208-217. doi: $10.13057 /$ biodiv/d 170130

Sälgeback, J., 2006. Functional Morphology of Gastropods and Bivalves. Acta Uniersitatis Upsaliensis Uppsala. $31 \mathrm{p}$.

Sobrizal, D., 2017. Potensi Pemuliaan Mutasi untuk Perbaikan Varietas Padi Lokal Indonesia. J. IImiah Aplikasi Isotop Rad., 12(1):23-36.

doi: 10.17146/jair.2016.12.1.3198

Soeharmoko., 2010. Inventarisasi jenis kekerangan yang dikonsumsi masyarakat di Kepulauan Riau. J. Dinamika Maritim, 2(1):45-53.

Srimariana, E.S., 2015. Potensi kerang manis (Gafrarium tumidum) di pesisir Pantai Negeri Laha, Teluk Ambon sebagai sumber mineral. Biodiv. J. Biol. Div., 1: 843-847. doi: 10.13057/psnmbi/m010431

Sunnucks, P., 2000. Efficient genetic markers for population biology. Trends in Ecology \& Evolution, 15(5):199-203. doi: 10.1016/S0169-5347(00)01825-5

Tahir, M.H. \& Akhtar, S., 2016. Services of DNA barcoding in different fields. Mitochondrial DNA Part A, 27(6):44634474. doi: 10.3109/19401736.2015.1089572

Tahir, H.M., Mehwish, Kanwal, N., Butt, A., Khan, S.Y., \& Yaqub, A., 2016. Genetic diversity in cytochrome c oxidase I gene of Anopheles mosquitoes. Mitochondrial DNA Part A, 27(6): 4298-4301. doi: $10.3109 / 19401736.2015 .1082104$

Tamura, K., Stecher, G., Peterson, D., Filipski, A., \& Kumar, S., 2013. MEGA6: Molecular evolutionary genetics analysis version 6.0. Mol. Biol. Evol., 30(12): 2725-2729. doi: 10.1093/molbev/mst197

Tindi, M., Mamangkey, N.G.F., \& Wullur, S., 2017. DNA Barcode dan Analisis 
Filogenetik Molekuler Beberapa Jenis Bivalvia Asal Perairan Sulawesi Utara Berdasarkan Gen COI. J. Pesisir Laut Trop., 1 (2):32-38.

Williams, S.T., 2007. Origins and diversification of Indo-West Pacific marine fauna: evolutionary history and biogeography of turban shells (Gastropoda, Turbinidae). Biol. J. Linnean Soc., 92(3):573-592. doi: $10.1111 /$ j.1095-8312.2007.00854.x

Williams, S.T., \& Ozawa, T., 2006. Molecular phylogeny suggests polyphyly of both the turban shells (family Turbinidae) and the superfamily Trochoidea (Mollusca: Vetigastropoda). Mol. Phylogenet. Evol.,
39(1):33-51. doi: 10.1016/j.ympev.2005.12. 017

Yuan, J., Zhu, Q., \& Liu, B., 2014. Phylogenetic and Biological Significance of Evolutionary Elements from Metazoan Mitochondrial Genomes. PLOS ONE, 9(1):1-13. doi: 10.1371/journal.pone.0084 330

Zabarun, A., 2016. Hubungan panjang berat, faktor kondisi dan rasio berat daging Kerang Pasir (Modiolus modulaides) di perairan Bungkutoko Kota Kendari. J. Manag. Sumberdaya Perairan, 2(1):2132. 